\begin{tabular}{|c|c|}
\hline \multirow{3}{*}{ 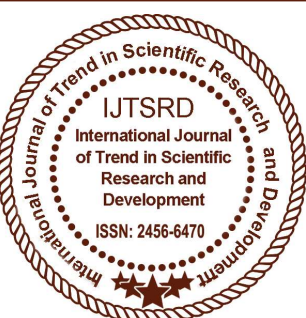 } & $\begin{array}{l}\text { International Journal of Trend in Scientific } \\
\text { Research and Development (IJTSRD) }\end{array}$ \\
\hline & International Open Access Journal \\
\hline & ISSN No: 2456 - 6470 | www.ijtsrd.com | Volume - 2 | Issue -3 \\
\hline
\end{tabular}

\title{
Committing Comedy Laughter as the Heresy of Worldliness in The Name of the Rose
}

\author{
Dhee Sankar \\ PhD Student and Junior Research Fellow, \\ Department of English, Presidency University, Kolkata, West Bengal, India
}

\begin{abstract}
A theoretical reclamation of the comic has been instrumental to the twentieth-century "linguistic turn" in literary criticism. Since Bakhtin's association of the "dialogic" with the "carnivalesque" and its later influence on the structuralists, laughter has graduated into a paradigmatic expression of the "ex-cess" postulated by postmodern philosophy. This role recycles but goes beyond the "satire" in earlier literary forms; in fact, in much of postmodern literature there has been an attempt to fictionally re-read medieval visual and verbal art forms as concurring with one or more aspects of the "sign" as formulated by continental philosophy, and such revisionist readings often involve a narrative transformation of the comic elements in them. Since the Renaissance was deemed to be the high point of humanism, the proponents of antihumanism looked to medieval Europe in search of historical prototypes. This tendency is exemplified by Umberto Eco's Italian historical novel, Il Nome Della Rosa (The Name of the Rose).
\end{abstract}

Explicitly self-conscious in its agency of authorship and underscoring its own intertextuality, this paragon of pastiche is a piece of tragic detective fiction which reads more like a treatise than a novel for most parts. Hardly is there a respite in the novel from the sombrely descriptive or confessional mode of narration of Adso of Melk, complicated by cumulative layers of historical, theological and eschatological erudition coming from Eco's training as a medievalist. In this regard, the novel is clearly Joycean; in his critical essay The Aesthetics of Chaosmos: The Middle Ages of James Joyce, Eco speculates about the significance of medievalism for a postmodern aesthetic: "the definitive choice is not made . . . There

is a development of a continuous polarity between Chaos and Cosmos, between disorder and order, liberty and rules." As a semiotician, Eco appropriates an endlessly proliferating reservoir of ancient texts to illustrate the phenomenon of "unlimited semiosis" theorized by him. This intervention accomplishes a cardinal stratagem : as Christina Farranto points out, "the whodunit is the ultimate postmodern genre, since postmodern authors quickly turn the detection process into a metaphysical search for truth." The integration of medieval and twentieth-century semiotics in the Holmsian discourse of William of Baskerville clearly tends to do this; however, it is precisely upon a deep disagreement over the nature of "truth" that the whole narrative hinges.

"Perhaps the mission of those who love mankind is to make people laugh at the truth, to make truth laugh," William comments in the novel's final chapter. The detective himself, then, is contending against a dogmatic devotion to the seriousness of "Truth", including divine truth. Eco's debt to Joyce thus extends beyond mere medievalism to its adaptation to humorous ends, underlining another implication of the poststructuralist word "play." Laughter plays almost an iconic role in The Name of the Rose, since it is nearly absent in the Gothic claustrophobia of the abbey and the godly gravity of its inhabitants, and finds a few tense, deprecatory mentions in theological debates, before making a momentous appearance at the climax, like an icon or holy grail does in the romances which partly inspire the novel's name. The plot pits Brother William's Franciscan and Thomistic understanding of religion against the apocalyptic blind prophet of doom, the "venerable" Brother Jorge. 
Moreover, being a "book about books", The Rose blooms around a book, a philosophy and a literary theory which itself exists only as a conjecture: a second book of Aristotle's Poetics, which focuses on comedy. Having found the only extant copy of the same, the bibliophile Brother Jorge hides it in the library for forty years, then finally embarks on a series of murders by poisoning the pages of the manuscript in order to punish inquisitive monks for reading it. Moreover, he synchronises the settings of the crimes with a series of apocalyptic images from St. John's Revelation, thus suggesting the sinfulness of the victims and frequently preaching it.

The debate centres around a medieval tradition in Catholic art and sculpture, called the mundus inversus or "inverted world" trope, which consisted in grotesque inversions of the "divinely created" real world; it appeared as miniatures and marginalia in editions of the Bible copied out by scribes in monasteries, and as frescoes on the walls of churches and abbeys. They were supposed to instruct through laughter, to disseminate the divine Word by vulgarizing it. As Bakhtin had observed, "In the wealth and variety of its parodic forms, the Middle Ages was akin to Rome. .. The literary and artistic consciousness of the Romans could not imagine a serious form without its comic equivalent.? parodying the direct word, direct style, exploring its limits, its absurd side." Bakhtin considered the novel to be ideal for carrying out this dialogue, and in The Name of the Rose, the dialogue turns fatally bitter. An attractive young monk named Adelmo had been a gifted illustrator of such comic pictures, and homosexual desire for him had incited two other monks to delve deeper into the secrets of the inviolable library. While investigating Adelmo's death, William learns about bitter debates between these monks and Brother Jorge on the pedagogical role of laughter; Jorge in fact attributes diabolical qualities to their praise of laughter and also to their insatiable thirst for knowledge. Both these monks are murdered in turn, but clues are left about a secret section of the library called the "finis Africae," where the Aristotle manuscript is hidden amongst heathen African poetry. Notably, the existence of this book had been first surmised through references to other books during this debate, and thus Jorge's suppression of one text is repeatedly foiled by intertextuality and by other people's competence at "reading" various signs - linguistic or otherwise.
Aristotle's treatise on comedy is discursively associated in the novel with non-European, nonChristian literature. It is bound up in a collection of manuscripts with Arabic and Syrian texts, and hidden in the Finis Africae; clearly, the plurality of perspectives promoted by laughter, which is advocated through the plot, is mapped on to racial plurality in the textual canon. Jorge detests the "heathen" authors as much as he does any comic take on the Christian Word. Heresy is an exigent issue in the given chronotope, with the Roman Inquisition impinging upon the Abbey's autonomy. The librarian censors books deemed to be heretical, and this includes many scientific treatises by "heathen" middle-eastern authors. However, once William and the narrator Adso explore the central reservoir of symbolism in the novel, the library itself, it becomes manifest that its structure exhibits a unique cultural hybridity. William points out that the optical illusions created by the mirrors meant to frighten trespassers are all explained by Arabic scholars, and large portions of its labyrinth are devoted to Asian and African books. Eco clearly borrows the library's labyrinthine aura, as well as its polygonal multistoreyed architecture, from Jorge Luis Borges's story "The ILibrary Co Babel", and even marks his indebtedness by naming his criminal mastermind Jorge of Burgos. Ian Almond has called Borges the first "post-Orientalist," and Eco borrows precisely this post-Orientalism from him. The Orientalist tropology is deployed in such a discourse not to otherize an imagined Orient, but to open up the ideological horizon into a heterotopia, where the Orient becomes illustrative of what Lyotard calls "the postmodern condition". The unlimited semiosis emblematized by the library throws up two elements which appear heretical to Brother Jorge : the possibilities of laughter and the possibilities of the natural sciences, both pioneered by non-Christian, 'other' authorities. Consequently, he speaks with the utmost contempt of an African alchemist's theory that the world was created from the divine laughter of God.

During the climactic debate between the sleuth and the killer, Jorge accuses William of heresy, decrying his dual allegiance to the teachings of St Francis of Assisi and the empiricist friar Roger Bacon. This comes together with persuasive arguments against Aristotle's book on comedy : "Laughter, for a few moments, distracts the villein from fear. But law is imposed by fear, whose true name is fear of God. This book could strike the Luciferine spark that 
would set a new fire to the whole world, and laughter would be defined as the new art... The day when the Philosopher's word would justify the marginal jests of the debauched imagination, or when what has been marginal would leap to the centre, every trace of the centre would be lost." He thus realises the decentring potential of laughter, and proscribes it for privileging imagination over faith and fear, just like science does. Worldly empiricism is considered heretical not because it is materialistic, but because objectivity is a function of the imagination which undercuts fear. This debate is not between faith and reason, but between faith in divine law alone and faith in the divinity of human imagination.

William turns Jorge's argument on its head by suddenly commenting, "You are the devil." He then goes on to refute the matter/spirit binary of Christian dogma. "The Devil is not the Prince of Matter; the Devil is the arrogance of the spirit, faith without smile, truth that is never seized by doubt. The Devil is grim because he knows where he is going, and, in moving, he always returns whence he came." The Devil always returns to the centre. Eco never relegates the traditional Christian categories of thought in his commitment to theory ; instead, a reversal takes place in them to legitimise decentring and humour through theology. Notably, this culminates in the actions of Jorge himself : the planning of murders and suicide according to apocalyptic verses of the Revelation is the ultimate parody of the Logos. Adso's narration sees another paradox in Jorge's unique suicide : "he began slowly tearing the limp pages of the poisoned manuscript, stuffing them into his mouth, slowly swallowing as if he were consuming the host and he wanted to make it flesh of his flesh." In this way, Jorge too internalizes Aristotle, and hence, "He laughed, he, Jorge. For the first time I heard him laugh. ... He laughed with his throat, though his lips did not assume the shape of gaiety, and he seemed almost to be weeping."

This diabolic, self-defeating laughter effectively constitutes the narrative as well as philosophical climax of The Name of the Rose. The prophet of high seriousness himself finally commits the "heresy" of comedy, and leads the plot to a tragic denouement. In fact, the dialectic between the opposing positions never reaches any completion, but instead explodes into a conflagration, turning the entire library, the entire history, into ash. This tragic novel about comedy is finally marked by a deafening silence where laughter should have been ; we are reminded of the idea of a strange heterological laughter in Derrida's Writing and Difference : "laughter alone exceeds dialectics . . . It bursts out only on the basis of an absolute renunciation of meaning, an absolute risking of death, what Hegel calls abstract negativity. A negativity that never takes place, that never presents itself . . . A laughter that literally never appears."

\section{Works Cited}

1) Almond, Ian. The New Orientalists: Postmodern Representations of Islam from Foucault to Baudrillard. London: I. B. Tauris, 2007. Print.

2) Davis, Debra Diane. Breaking Up (at) Totality: A Rhetoric of Laughter. New York: Southern Illinois University Press, 2000. Google Books. Web. 9 Nov 2017.

3) Derrida, Jacques. Writing and Difference. London: Routledge, 2002. Print.

4) Eco, Umberto. The Name of the Rose. Trans. William Weaver. New York: Warner Books, 1980. Print.

5) Farranto, Christina. Eco's Chaosmos: From the Middle Ages to Postmodernity. Toronto: University of Toronto Press, 2003. Google Books. Web. 9 Nov 2017. 